\title{
ОПТИМІЗАЦІЯ ПІСЛЯДИПЛОМНОЇ ПІДГОТОВКИ МЕДИЧНИХ СЕСТЕР З ПИТАНЬ ПАЛІАТИВНОЇ ТА ХОСПІСНОЇ ДОПОМОГИ НАСЕЛЕННЮ В УКРАЇ̈I
}

\author{
А. О. Боб ${ }^{1}$, О. О. Чукур ${ }^{1}$, І. О. Воронюк ${ }^{2}$ Л. З. Ференц ${ }^{3}$ \\ ${ }^{1}$ Тернопільський національний медичний університет \\ імені І. Я. Горбачевського МОЗ Украӥни \\ ${ }^{2}$ Вінницька міська клінічна лікарня швидкої медичної допомоги \\ ${ }^{3}$ Комунальне некомериійне підприємство Львівської обласної ради \\ «Львівська обласна клінічна психіатрична лікарня"
}

\begin{abstract}
У статті представлено сучасні підходи і методи безперервної професійної підготовки медичних сестер 3 питань надання паліативної та хоспісної допомоги населенню, що набуває особливого значення за умов реформування системи охорони здоров’я в Україні. Показано, що оптимізація додипломної і післядипломної професійної підготовки медичних працівників з питань паліативної та хоспісної допомоги має велике значення для забезпечення високої якості надання медичної допомоги населенню і вимагає в процесі безперервної післядипломної освіти проведення циклів тематичного удосконалення, семінарів, тренінгів, стажувань, навчальних поїздок та роботи в тренінгових центрах.
\end{abstract}

\section{OPTIMIZATION OF THE POSTGRADUATE NURSING EDUCATION ON PALLIATIVE AND HOSPICE CARE IN UKRAINE}

\author{
A. O. Bob' ${ }^{1}$ O. O. Chukur ${ }^{1}$, I. O. Voronyuk ${ }^{2}$, L. Z. Ferents ${ }^{3}$ \\ ${ }^{1}$ I. Horbachevsky Ternopil National Medical University \\ ${ }^{2}$ Vinnytsia City Clinical Medical Emergency Hospital \\ ${ }^{3}$ Communal Nonprofit Enterprise of Lviv Regional Council \\ "Lviv Regional Clinical Psychiatric Hospital"
}

\begin{abstract}
The article describess modern approaches and methods of continuous professional trainings for nurses in providing palliative and hospice care of patients, which acquires special significance in the context of health care reform in Ukraine. It is shown that the optimization of undergraduate and postgraduate education of medical workers in palliative and hospice care is important to ensure high quality of medical care and requires cycles of thematic improvement, seminars, workshops, internships, study trips and work in training centers in the process of continuing postgraduate education.
\end{abstract}

Вступ. Демографічне старіння населення України, зростання кількості людей похилого і старечого віку в загальній структурі населення призводять до значного збільшення професійного навантаження медичних сестер для надання їм медичної та паліативної допомоги.

Роль медичної сестри і значний обсяг її мультидисциплінарних функціональних обов'язків при наданні якісної медичної допомоги всім категоріям населення набуває важливого значення, особливо за умов реформування системи охорони здоров'я в Україні,

(C) А. О. Боб, О. О. Чукур, І. О. Воронюк, Л. З. Ференц, 2021 яка полягає не тільки в структурних і фінансово-економічних змінах, а й в забезпеченні кваліфікованими медичними кадрами. Безперервна освіта $€$ на сьогодні пріоритетним напрямком розвитку освіти України в процесі її інтеграції в світовий та європейський простір і розглядається як важлива умова підвищення якості медичної допомоги населенню [1].

Основна частина. В Україні впродовж останнього десятиліття швидкими темпами розвивається система паліативної та хоспісної допомоги (ПХД) як інноваційний напрямок охорони здоров'я та соціального захисту населення, який покликаний поліпшити якість 
життя інкурабельних хворих та членів їхніх родин. Одним з основних завдань сучасної професійної підготовки медичних працівників у галузі ПХД повинно стати формування у них пацієнт-сім'я-орієнтованої позиції, навичок мультидисциплінарної та командної співпраці [2]. Тому важливо забезпечити ретельний відбір і відповідну мотивацію медичних кадрів. До надання ПХД після відповідної професійної підготовки можуть залучати лікарів будь-якої спеціальності, медичних сестер центрів первинної медико-санітарної допомоги (ПМСД) і амбулаторій та стаціонарних закладів охорони здоров'я (303), а також фельдшерів сільських ФАПів.

Сучасна ПХД висуває високі вимоги до медичних сестер, які не тільки повинні мати глибокі знання 3 догляду за хворими, клінічної медицини, фармакології та психології, але й володіти навичками спілкування, бути чуйними і милосердними, вміти працювати в мультидисциплінарній команді. Медичні сестри, які працюють у стаціонарних 303 ПХД, крім вищезазначених знань та вмінь, мають знати особливості перебігу захворювань у термінальних та декомпенсованих стадіях, основи танатології, розуміти і адекватно реагувати на психоемоційний стан пацієнта та його рідних, володіти навичками співпраці у складі медичної допомоги бригади/команди з іншими медичними спеціалістами та фахівцями немедиками. До процесу надання ПХД і догляду за паліативними пацієнтами, крім медичних працівників, залучають психологів, соціальних працівників/робітників, юристів та священнослужителів, волонтерів, представників місцевих громад та приватних структур, а також членів їхніх сімей або опікунів.

Медичні працівники, які надають ПХД, мають бути готовими реалізувати головне завдання паліативної медицини: якщо пацієнта не можна вилікувати, потрібно зробити усе можливе, щоб полегшити біль і страждання, допомогти зберегти людську гідність та забезпечити належну якість життя паліативного пацієнта.

Відповідно до сучасних міжнародних підходів, усі спеціалізовані служби ПХД повинні мати у своєму розпорядженні належним чином мотивовані лікарські та сестринські кадри, які мають спеціальну підготовку і склали іспит з питань ПХД. У багатьох країнах таку підготовку проводять на 3-ох рівнях: 1) базовий рівень для всіх медичних працівників; 2) середній рівень для підвищення кваліфікації медичних працівників окремих спеціальностей; 3) вищий (спеціалізований) рівень - для лікарів і медичних сестер, які здобувають спеціалізацію з паліативної та хоспісної медицини або працюють в закладах ПХД [3].

Для підвищення якості надання ПХД та мотивації медичної допомоги до безперервного професійного розвитку з питань ПХД велике значення мають затвердження відповідної спеціалізації/субспеціалізації «Паліативна і хоспісна медицина» та введення в Україні в номенклатуру спеціальностей лікарів та молодших медичних спеціалістів медичної спеціальності «Лікар з паліативної і хоспісної медицини» та «Молодший медичний спеціаліст з паліативної і хоспісної медицини», як це має місце у багатьох країнах світу. Зокрема, паліативна медицина визнана самостійною спеціальністю або самостійним напрямком медицини у рамках окремих спеціальностей в Ірландії в 1995 р., у США - в 1996 р., у Новій Зеландії та Гонконгу - в 1998 р., у Швеції і Польщі - в 1999 р., у Румунії - в 2000 р., у Тайвані - в 2001 р., в Австралії та Словаччині - у 2005 р., у Німеччині - в 2006 р., у Франції - у 2007 р. [4, 7].

У зв'язку з відсутністю в Україні лікарської та медсестринської спеціальності «Паліативна та хоспісна медицина» післядипломну підготовку та підвищення кваліфікації фахівців закладів охорони здоров'я 3 питань ПХД здійснюють на курсах тематичного удосконалення. У навчальних програмах професійної підготовки медичних сестер, які надають ПХД, крім знань і навичок контролю хронічного больового симптому та інших станів у паліативних пацієнтів, вивчають методи оцінювання стану пацієнта за відповідними шкалами, користування медичним обладнанням та засобами догляду за паліативними хворими і контролю їх виконання молодшими медичними працівниками, родичами або доглядальниками. Це, зокрема: догляд за стомами (цисто-, гастро-, трахео-, колостомами), центральним венозним катетером, вентрикулоперитонеальним шунтом, забезпечення оксигенотерапії (концентратор кисню), контролю $\mathrm{SaO}_{2}$, зондового або парентерального харчування та гідратації тощо. Надаючи ПХД вдома, медична сестра разом із доглядальниками та членами сім'ї повинна вміти забезпечити належну гігієну тіла паліативного хворого, догляд за шкірою, ротовою порожниною, годування хворих через стому або зонд, профілактику та лікування пролежнів, обробку різного виду ран, забезпечення спорожнення кишечника, катетеризацію сечового міхура, обробку стом тощо [5].

У навчальних програмах безперервного професійного розвитку медичних працівників в Україні необхідно також приділяти увагу вивченню оптимальних 
організаційних заходів протидії та подолання професійного вигорання у персоналу 303 ПХД та осіб, яких залучають до надання ПХД [6]. Крім того, медичні працівники, які надають ПХД, разом із психологами та соціальними працівниками мають бути готовими опікуватися і членами сім'ї паліативного пацієнта як у період хвороби, так і після смерті пацієнта, що дозволить зменшити шкідливу дію стресу, горя і негативних емоцій, забезпечити профілактику, ранню діагностику і своєчасне лікування психосоматичних захворювань. Знання етики і деонтології, спілкування, поєднане з високим професіоналізмом, сприяє успішному подоланню труднощів, що виникають у паліативних хворих наприкінці життя, тому ці питання мають обов'язково бути включені до програм підготовки медичних сестер. Робота з сім'ями паліативних пацієнтів є складною, забирає багато часу, але вона вкрай необхідна, адже це дає можливість підвищити якість життя таких хворих, що є головною метою ПХД. Неминуча і близька смерть рідної людини зумовлює загрозливу/кризову ситуацію для членів сім'і - у сім'ях відбуваються порушення звичного сімейного укладу, фінансового та морально-психологічного стану. Тому адекватну медичну та психологічну допомогу мають отримувати також і члени сім'ї. Часто медико-психологічний супровід членів сім'ї продовжується і після смерті пацієнта. Тому медичним працівникам також необхідні педагогічні уміння та навички, щоб навчити пацієнта і його родичів елементам догляду, гігієни та контролю симптомів [7].

3 метою запровадження та оптимізації системи підготовки медичних фахівців із питань ПХД, що є умовою забезпечення якості та доступності надання ПХД населенню, проводять цикли тематичного удоско-

\section{СПИСОК ЛІТЕРАТУРИ}

1. Бугаєвська Н. А. Особливості становлення та розвитку паліативно-хоспісної допомоги в Україні / Н. А. Бугаєвська // Медсестринство. - 2017. - № 1. - С. 65-68.

2. Гойда Н. Г. Соціально-медичні аспекти розвитку паліативної та хоспісної допомоги в Україні в умовах реформування системи охорони здоров'я / Н. Г. Гойда, Ю. І. Губський, А. В. Царенко // Реабілітація та паліативна медицина. - 2015. - № 2-3 (1). - С. 23-30.

3. Вороненко Ю. В. Створення системи паліативної та хоспісної допомоги в умовах реформування охорони здоров'я в Україні: медичні та соціальні аспекти / Ю. В. Вороненко, Ю. І. Губський, А. В. Царенко // Наука і практика. - 2014. - № 1. - С. 63-75.

4. Данилюк К. В. Сучасний зарубіжний досвід застосування організаційного механізму державного налення для лікарів та середніх медичних працівників, спецкурс для лікарів-інтернів, які навчаються за спеціальністю «Загальна практика - сімейна медицина», та вивчення окремої навчальної дисципліни в програмі післядипломної підготовки медичних сестербакалаврів і магістрів. Певний досвід післядипломної освіти середніх медичних працівників із питань ПХД $\epsilon$ в тренінговому центрі Навчально-наукового інституту медсестринства Тернопільського національного медичного університету імені І. Я. Горбачевського. Викладачі вдосконалили навчально-методичну базу до- та післядипломної підготовки середніх медичних працівників із надання ПХД, зокрема розробили та затвердили уніфіковані навчальні програми, написали підручники, посібники, рекомендації. Підготовку медичних фахівців із ПХД проводять під час різноманітних семінарів, тренінгів, стажувань та навчальних поїздок, які здійснюються за участю державних установ МОЗ України та міжнародних організацій, фондів і партнерів.

Висновки. На сьогодні актуальною проблемою в Україні $\epsilon$ створення системи безперервної професійної підготовки медичних працівників із питань паліативної та хоспісної допомоги, оскільки адекватна додипломна підготовка та безперервний професійний розвиток кваліфікованих фахівців є однією з головних умов створення і розвитку системи якісної та ефективної паліативної та хоспісної допомоги. Це вимагає створення відповідної системи післядипломної освіти, впровадження моделі безперервної професійної підготовки медичних працівників із питань паліативної та хоспісної допомоги, ретельного відбору і відповідної мотивації кадрів.

управління паліативною та хоспісною допомогою / К. В. Данилюк // Вісник НАДУ при Президентові України. 2017. - № 2. - С. 79-86. - (Серія «Державне управління»).

5. Дані для паліативної допомоги: міжнародний досвід, українська практика, стандарти, індикатори, оцінки / А. Горбаль, Є. Горох, Р. Насрідінов [та ін.]. - К. : Український центр суспільних даних, 2018. - 60 с.

6. Губський Ю. І. Розвиток паліативної та хоспісної медицини як інтегральна складова реформування системи охорони здоров'я в Україні / Ю. І. Губський // Сімейна медицина. - 2011. - № 3. - С. 16-18.

7. Amery J. A Really Practical Handbook of Children's Palliative Care for Doctors and Nurses Anywhere in the World / J. Amery. - Lulu Publishing Services, 2016. - 446 p. 